\title{
Cooperative modulations: the antimafia movement and struggles over land and cooperativism in eight Sicilian municipalities
}

\author{
Theodoros Rakopoulos \\ University of Pretoria
}

\begin{abstract}
Debate on the antimafia movement has placed the phenomenon mainly in the urban civil society tradition of new Italian social movements. While acknowledging the resonance of antimafia mobilization in this context, this article explores a different tradition, wherein struggles against the mafia in Sicily are analysed alongside, and in constant interconnection with, the development of the agrarian cooperative movement of the island. Focusing on the Alto Belice area of western Sicily, the article argues that antimafia politics evolved from an association with agricultural workers' cooperativism in an anti-middleman direction after the 1950s land reform. Moreover, it assesses ethnographically how this tradition has influenced actors in the contemporary, largely successful, movement of antimafia cooperatives that cultivate land confiscated from the mafia by the Italian state. It examines how these actors link to this genealogy, associating their contemporary activity, in largely imaginary ways, to this history of struggles, and claiming inheritance over it.
\end{abstract}

Keywords:: Mafia, antimafia, cooperatives, Sicily, land reform, legality.

\section{Antimafia cooperatives}

Since 1996, in western Sicily, the Italian state has been confiscating agricultural land and other assets from mafiosi leaders arrested in the area. Some of the confiscated land has been bestowed on local agricultural cooperatives, in the area of Alto Belice, Palermo's agrarian hinterland ${ }^{1}$ (Pati 2010). These 'antimafia cooperatives' (as they are known locally) have been operating since 2000 . They comprise about 100 members, plus seasonal waged workers as needed. Today's antimafia agricultural cooperatives are continuous with various formations of cooperativism dating back to the 1890s - an impressive genealogy. This article is concerned with how the antimafia movement has been intertwined with cooperativism in rural western Sicily, and looks at the processes in which their actors have overlapped through time. Historicized, the relations between mafia, antimafia and cooperatives can be understood equally in terms of the continuity of practices and, in their transformations. This narrative takes both a historical and ethnographic form, to provide an explicatory overview of the rise and development of the rural antimafia phenomenon.

The article's aim is twofold: first, to identify the key moments of reference in the history of the antimafia movement for members of contemporary antimafia cooperatives, building a historiography from the views and experiences of my research participants; and second, to examine specific readings of history, regarding these moments, by current antimafia actors to assess the movement's legacy and embed the contemporary cooperatives within a framework of ideas largely indigenous to Sicily, which resonate today with both urban civil mobilization 
and rural cooperativism ('legality', and 'antimafia' itself). In this way, the article contextualizes historically the dynamic interactions between peasant politics, state, mafia and antimafia, as these emerged in Alto Belice.

The article therefore traces the historical points of reference for current actors of Sicily's antimafia movement; aiming to explore the genealogy of the notion, it follows peasant mobilizations, assessing the impact of this tradition on current antimafia cooperativism. The selective ways in which contemporary participants reflect on the history of the antimafia movement, commemorating it and updating its meaning for today, illuminate current meanings of 'antimafia', a concept indigenous to Italy and central to its political climate (Santino 2006; Scolaro 2008).

\section{Modular notions: method and theory}

While it may be understood in general terms of guiding principles, cooperativism in Alto Belice has had varying meanings at different times. An approach to cooperativism, through a historical ethnography, therefore needs to give an account not only of its broad manifestations but also of its particular social relationships on the ground. Thus, I conceptualize cooperativism as a 'modular' notion that possesses certain core characteristics, but which changes in form and content in relation to the specific contexts in which the 'module' is developed and deployed. Here, I am drawing on Benedict Anderson's approach to nationalism, nationality and nation-ness as cultural artefacts, which came into historical being in specific circumstances and became 'modular', capable of being transplanted, with varying degrees of self-consciousness, to a great variety of social terrains, to merge and be merged with a correspondingly wide variety of political and ideological constellations (Anderson 2006, 4).

Anderson's account suggests a notion that, in turn, allows portability and distillation in new contexts. Contemporary Sicily, undergoing changes influenced by the ensemble of mobilizations dubbed 'the antimafia movement', is an ideal site to explore how cooperativism relates to social change (Fiume 2006). Locating this question in historical time helps explore how the interrelationship of mafia and peasant struggles has been negotiated in the context of the island's ongoing experience of change, of which (different meanings and practices of) 'antimafia' is a major vector, as noted by regional research (Davis 1996; Schneider and Schneider 2006).

Specific circumstances on the ground (mafia activity and the peasant movement's antimafia responses) have rendered peasant cooperativism a practice both distinct in its Sicilian specificities and contextualized in two different moments in Alto Belice's modern history. The first set of circumstances relates to communalist worker-based cooperativism in the 1940s, the second set to post-agrarian-reform, producer-based cooperativism, premised on small-proprietor viticulture. I show that the cultural meaning of cooperativism in Sicily derives from circumstances in these two periods, both of which were informed by antimafia commitment. In that respect, the article explains how cooperativism became a model of economic organization and a political ideal of organization to avoid the mafia, alongside exploitative landlords and distant urban markets. In the final section, I examine and analyse, via primary data gathered from ethnographic fieldwork, how this history has been 'transplanted' in the current configuration of antimafia cooperatives, to form a third form of cooperativism. 


\section{Sicilian debates: the antimafia movement}

By elucidating how peasant movements in western Sicily were organized around antimafia in terms of cooperativist claims and practices, by framing the meanings of antimafia politics in peasant mobilization, and by underlining interactions between gaining a livelihood and struggling against the mafia, this article aims to contribute to the regional scholarship of Sicily and, specifically, to the history of the antimafia movement. The regional literature, predominantly focused on urban developments, identifies the antimafia phenomenon as a civil society mobilization and as an institutional activity, the latter often in response to such mobilization (Jamieson 2000; Orlando 2003). Italian activism at large has been tackled sociologically mainly in that respect (Giorgio and Cento Bull 2005), and the Palermitan antimafia movement is no exception: it has been located in social movement as well as institutional change theory (Girolamo 2009). Some scholarly work at times associates the social struggles against the mafia with behavioural change and educative reform (Gunnarson 2008), drawing from debatable arguments on the lack of trust in Sicily's civic sphere (Gambetta 1996). Analogies to such approaches can be found in studies of anticorruption initiatives that claim to be rooted in grassroots needs but are quickly institutionalized as 'grant-seeking' formations (Sampson 2005).

Such ideas might benefit from a historical ethnography that situates contemporary actors' activities and ideas in historical time, endorsing a move away from culturalist particularization. This means challenging the last remaining assumptions about Sicilian tolerance for mafia values rooted in 'cultural codes', as Michael Blim $(2006,10)$ has suggested in a review of anthropologists Schneider and Schneider's older work. In their 1996 monograph on Sicilian demography, however, the Schneiders had admittedly already traced and highlighted, mostly among artisans, a not necessarily 'antimafia', but certainly 'alternative', set of 'enlightened' social sensibilities (Schneider and Schneider 2006, 76). As they acknowledge in a self-reflective article, the importance of the movement escaped them in their first Sicilian fieldwork, situated in a rural community (75). Later fieldwork in Palermo produced a monograph in which the antimafia movement is rigorously discussed as simultaneously a prism, a vector and an outcome of social change on the island (Schneider and Schneider 2003). Here, the researchers acknowledge the peasant roots of the movement (1997) and suggest its gradual transplantation from agrarian to urban settings (2002). In this vein, the work of Umberto Santino (2009) should also be considered, despite the analytical framework based on class relations that suggests an evolutionist perspective as well as a pessimistic political suggestion that the movement lost its historical significance when urbanized.

These works, suggesting the move from rural to urban settings, and to an extent the corresponding emphasis on class configurations (and shifts in work and labour patterns; as per Cole 1997, 2007), are an inspiration to this article's narrative, in that they grasp a sense of continuity alongside transformation (which serves as a grounding for the notion of modularity). They call also, however, for complimentary research on the material and symbolic legacy of the roots of the antimafia movement in rural environments today - which can benefit through conceptualizing the interrelationship of political commitment and relations of production in Sicily and Italy at large. To this end, reassessing the rural antimafia movement today relocates the historical, ideological meanings of legality from civil society into agrarian production and distribution, building on previous points on Sicily's dynamic, plural cultures (Schneider and Schneider 2005). 
These elements interacted with each other in various ways, to the point at which, in certain instances, they became intertwined, producing ideological specificities unique to Sicily which still resonate with contemporary developments. Explicit or implied 'antimafia' policy is an aspect of peasant mobilization particular to Sicily's peasant cooperativist history and is central to assessing how moral economy elements in contemporary agrarian movements are rooted in specific readings of historical data (Edelman 2005). The lens through which I propose to review this history and assess the ways it resonates with contemporary actors is by approaching antimafia peasant sensibilities and cooperative organization as modular schemes guided by peasants themselves, but framed in broader configurations of political economy that peasants can influnce only to an extent, as they are otherwise shaped by political institutions removed from rural Sicily (Mcmichael 2008).

\section{Land and dissent}

\section{The Fasci movement (1892-1915): the birth of the antimafia}

I begin my historical narrative with the Fasci Siciliani dei Lavoratori (Sicilian Workers Leagues) of the 1890s peasant movement, for both historical and ethnographic reasons. The first is informed by the existing historiography of peasant mobilization in Sicily, the second on my ethnographic observation of how, today, people historicize the antimafia movement's past. On the one hand, the Fasci contributed to a seminal change in the way agrarian labour relations are legislated in Sicily and Italy, as well as a reformulation of the island's relationship to the nation, one generation after Unification. The 'Corleone agreements', the first trade union collective contract in Italy, an outcome of this mobilization, confirm the Fasci's centrality in modern Italian history. The Fasci have been hailed as representing 'the birth of the antimafia movement' (e.g. Santino 2009, 16; Scolaro 2008).

On the other hand, when asked about the most significant moments in the history of the antimafia movement, my oldest informants, men between 60 and 80 years of age, who were sympathetic to the antimafia cooperatives, responded by listing the Fasci, the post-World War II land occupation movement, and the 1960s cooperative movement. Their historical awareness was enriched by genealogical narrative: their grandfathers had lived memories of the Fasci. Members of today's antimafia cooperatives often refer to the Fasci as 'the ancestor of antimafia cooperativism'.

The Fasci movement was a federation of braccianti, ${ }^{2}$ which had a mixed (socialist and Catholic) background, aimed at the collectivization of the latifundia, and drew together landless peasants as well as artisans, regardless of gender or age, to demand better work conditions. Fasci-coordinated groups of braccianti occupied landed estates, challenging Palermo-based proprietors' absenteeism, and formed impromptu cooperatives to cultivate these lands. Leading Alto Belice trade unionists were imprisoned in 1894, after the movement was crushed by the state.

The Fasci have been described as socialist or even anarchist (Ganci 1977). Marxist scholars reject the idea that the movement was a 'spontaneous', jacquerie-type outgrowth, insisting on its crucial role in late nineteenth-century labour movement (Renda 1977, 328; Santino 2009). Kautsky hailed the Sicilian 'braccianti' as 'the centre of the sympathies and thoughts of the international proletariat' (quoted in Romano 1959, 547). Labriola reported to Engels about the Fasci as a mixture of 'socialism, anarchism, business and mafia' (in Santino 2009, 33). Mafia and antimafia often interpenetrated in the development of the peasant movement. 
Bernardino Verro, a leading figure of the movement in Corleone, the large interior town that was its centre of gravity, even joined the mafia himself (Dickie 2004, 171), hoping to provide impetus to the Fasci through alliances with mafiosi who were also opposed to the state. After martial law suppressed the Fasci in 1893, a massive peasant exodus from Sicily took place, largely owing to fear of state and mafia retaliations. Verro, for instance, went to prison until 1896, though he subsequently became the town's mayor in the first elections after the introduction of universal suffrage. Capitalizing on his Fasci involvement he sought to establish agrarian cooperatives anew, but was eventually assassinated by local mafiosi in 1915 (Paternostro 1994, 48).

Forming a 'historical bloc', the state allied with latifundists after the Fasci (Gramsci 2010, 67); mafiosi, foreseeing the violent demise of the Fasci, opportunistically joined the alliance, solidifying the 'historical bloc', despite having temporarily allied with the peasant movement (Lupo 1981). The example of Verro illustrates the Fasci movement's intricacies: the fuzzy conceptual boundaries between mafia/antimafia led to mutual reproduction and eventual cross-fertilization, especially in times of social upheaval against a conservative state, regarding widespread claims for resources. Conversely, the mafia arose within peasant mobilization before turning against it: before they resorted to violence, mafiosi incorporated and emulated the social alliances they could not control. This has been a key reason for the relative social consensus the mafia has historically enjoyed.

\section{Inter- and post-war configurations: rural communism, law and violence}

In spite of the reputed Fascist state's opposition to the mafia, Fascism did not challenge the latifundo system's vested interests in maintaining the gabelloti, the mafia patrons at the time middlemen in the agrarian labour market. Local fascists were affiliated with mafiosi and so the latifundia protection (which relied on gabelloti) was left intact. Gabelloti landholding was a service to the absentee landowners of the big Sicilian estates; in that respect, they occupied middlemen positions between different levels of power, local and broader, securing the landlords' profits through violent means of controlling the local agrarian landless workforce (Blok 1974, 33).

The reproduction of the agrarian bloc within Fascism suggests mutual interests of state and mafia (Lupo 1981). Mussolini's 'commitment' to eradicating the mafia was therefore mere political rhetoric. Affluent mafiosi actively participated in dissolving agrarian cooperatives alongside the fascist police. On a wider scale, anti-socialist sentiment shared by fascists and mafiosi aggravated mass labour emigration abroad or to northern Italy, especially for the radically politicized in the braccianti movement (Schneider 1990).

Towards the end of World War II, the mafia capitalized on historical changes: links between Sicilian and US Cosa Nostra assisted the Allied invasion of Sicily (Summer 1943), via flows of intelligence from the mafia to the US Navy (Follain 2005). The widely held assumption that the US Army reciprocated for this cooperation, assisting mafia political influence across the island during the 'transition to democracy' is, however, debatable (Lupo 2011, 21-33); but Cosa Nostra helped to contain the spread of communism to Sicily after the leftist Resistance to Fascism spread in northern Italy (Robb 2009, 125).

Meanwhile, the Alto Belice braccianti, influenced by the Communist Party (PCI), took to the fields en masse, occupying the estates under the slogan 'give the land to those who work it', thus contributing to the latifundo's collapse (Blok 1974, 83). The political future that 
braccianti demanded was the collective ownership of the latifundo. The post-war impetus allowed peasants to seize land and transform the latifundist exploitative system of production. Events such as the occupation of the Alto Belice Drago estate in October 1946 by 4,000 peasants, who formed cooperatives to cultivate it, are typical of the movement (Di Matteo 1967, 484). Palermo: G. Denaro., 484). Immediately post-World War II, the braccianti, in a revival of the Fasci, organized communitarian uses of land on the occupied latifundia (Santino 2009), despite 'the anti-bolshevik crusades' of mafia patrons and their co-opted bandits, like the infamous Salvatore Giuliano (Dickie 2004, 210).

Post-World War II land occupations and workers' cooperatives lasted from the Liberation (Autumn 1943) to the Portella massacre, in Alto Belice (Spring 1947). What marks this period is that the movement's legalist claims found a response and basis for actions in the Gullo decrees ${ }^{3}$. The decrees represented a basis for peasant mobilizations and cooperativism that corresponded to the peasantry's 'legalist sense of justice' (Rossi-Doria 1983, 114), as interactions between peasants and political power centred on legislative procedures. Alto Belice experienced the 'entrenched legalism of peasant land invasions' (Hobsbawm 1974 124).

The decrees were laws initiated by the PCI minister of agriculture (Fausto Gullo) in the Italian Coalition government formed in April 1944 ${ }^{4}$. The minister's policies were embraced by the southern peasantry. Delighted with the cooperative movement, Gullo and his party thought that the extension of cooperative property might offer an impetus for communist influence in Sicily. In the 5th PCI Congress, Gullo and Ruggero Grieco (prominent MPs in the Constituent Assembly) proposed that:

at all costs, we have to direct the activities of the cooperatives towards collective forms of management.... We always have to search cooperativist forms, to encourage the peasants to renounce the constant fragmentation of land [that a reform would bring about]. (in Renda 1977 Renda, 60)

A delay in implementing the law angered braccianti, who started applying it de facto, occupying the latifundia and forming cooperatives to manage them.

The communist minister's law proposal expressed solidarity with the peasantry, aimed to capitalize politically on the movement's legalism, and supported cooperativist management of land in Sicily as a projection of a collectivist future. ${ }^{5}$. The revolutionary legality of the landless peasants was coupled with the most progressive agricultural law in Italian history, allowing braccianti to impose, through activist means, legislation suspended by the Italian state.

In the regional elections that took place in Sicily on 18 April 1947, the People's Block (Blocco del Popolo, a coalition of the PCI and the socialist party), came first, gaining 30.4 per cent of the vote, and shook the political system. The peasant movement's militancy, coupled with parliamentary representation aimed to establish a fair agrarian reform that would promote cooperativism.

At Portella on May Day 1947, as a crowd of landless peasant families gathered to celebrate a day of rest and post-election political euphoria, gunfire into the crowd caused mayhem. Thirteen people from the rural towns of Alto Belice were killed and dozens wounded. Scattering, people ran across the hills and back down towards their homes. No one could tell 
at that point who was shooting: 'bullets came from all sides' (Casarrubea 2005, 250). That the action was promoted by a combination of state secret services, Giuliani's bandits and mafiosi is yet to be proven; but this theory is widely held in Alto Belice today - as much as the belief that Portella was a warning against the peasant cooperativists to restrain their radicalism. Indeed, the final blow to their political radicalism came soon after with the longawaited 1950 agrarian reform.

\section{The agrarian reform}

Researchers regard the 1950 land reform in Sicily as a 'failure' (Schneider and Schneider 1996, 250-254), 'a failed land reform' which had 'political intentions' (Blok 1974, 79), or an 'anti-reform' or 'counter-reform' (Santino 2009). Since the late 1920s, the PCI had been critical of the long-awaited reform; as Gramsci pointed out:

The Turin communists ... warned against 'miraculist' illusions in a mechanical sharing out of the big estates.... What can a poor peasant achieve by occupying uncultivated or poorly cultivated lands? Without machinery, without accommodation on the place of work, without credit to tide him over till harvest-time, without cooperative institutions to acquire the harvest.... $(1971,5)$

With the application of the Gullo decrees to the uncultivated and poorly cultivated lands, the swiftly constituted grassroots agrarian cooperatives managed land across more people, in comparison to the post-reform situation. Cooperatives in 1946 shared more than 86,000 hectares, among their 50,000 members, while the social base of the state's agrarian reform reached in 1950 was more limited in scope (about 25,000 people). Moreover, the earlier cooperativist organization that enabled peasants to bargain collectively in urban markets was substituted by a smallholder economy. The 1950 law aimed at shaping a small-proprietor class, offering land to individual families as opposed to collective organizations. It hence discouraged the formation of workers' cooperatives and thus simultaneously deprived the locals of what had been their main means of political and antimafia organization. Many peasants, bereft of credit facilities and of the means of production other than land, became vulnerable, resulting in another wave of mass emigration in the 1950s.

Fragmenting land into family tracts therefore, destroyed radical bracciante cooperativism. Pratt makes a similar case for the 1953 reform in Tuscany, where 'a class of family members emerged not through market forces but through the direct action of the state' $(1994,63)$, arguing that the de-radicalization of the PCI-sympathetic ex-sharecroppers was the political aim of the land reform. Gaining not only access to markets but also bargaining power became the peasantry's aim in this new context; this meant sidelining brokers, the role that mafia had come to monopolize.

Antimafia mobilization interacted with legal and policy frameworks and informed the shift from workers' cooperativism to producers' cooperativism. There has been a shift in the focus of political struggles regarding alliances, claims and agents, from struggles over land to struggles over markets, in which mafiosi re-emerge as powerful middlemen in the role of market brokers (sensali), the pivotal, shifting moment being the agrarian reform legislation ${ }^{6}$. 


\section{'Sensali' brokers and cooperative wineries (1960s)}

Peasant integration into broader organizational structures took place through struggles to organize the vinification processes, after a gradual transformation from dry farming and pasture into wine grape cultivation. This was pivotal for political alliances and relationships against the local mafia. Exploitation by mafia brokerage and the political commitment of some locals produced local paths towards cooperativism, as peasants sought to reach urban markets. The cooperative winery developed into the basic unit of production around which interests of various social groups and individuals overlapped, regarding political mobilization and antimafia organization.

Alto Belice viticulturers established cooperative wineries for grape processing and engaging with the wine trade, integrating production and commercialization processes. Viticulture peasants focused first on the process of transforming the fruit into a finished product, identifying common ownership of technological means to make wine at reduced costs as the way forward, organizing themselves collectively while retaining their families' economic autonomy. As the old (pre-reform) co-ops gave way to a new form of cooperativism, cultivators continued the communitarian legacy of the braccianti movement while building on the new property dynamics instituted by the reform. The ideology of class was now linked to the 'autonomy' of the household, as noted in a historical ethnography of a viticulture economy in south-western Sicily (Schneider and Schneider 1996).

With land reform, vine growers in Alto Belice experienced a fairly rapid transition from being braccianti to occupying (unstable) positions in new class formations. In guaranteeing a piece of vineyard to each family, the reform had tackled only one economic grievance. The problem, which inspired cooperative wineries, was the speculative power that the mafia exercised in determining the price of the grapes. Even in the latifundist period, a rising class had moved out of rent-capitalism to become middlemen (Blok 1974, 67), setting the price of grapes (Bandiera 2003); Schneider and Schneider call this mafia activity 'broker capitalism' $(1976,160)$. Viticultivators needed to process the produce; the establishment of cooperative wineries came as an outcome of this concern.

In Alto Belice, 'broker capitalism' was identified with the figure of the sensale, central to the hinterland's integration into urban markets. The sensali worked for wine merchants in Palermo, Rome or abroad, buying the harvests of independent producers at low prices. Creating a relative degree of consensus and coordination with each other, they became systemic to the commercialization of wine. Thanks to this coordination, different mafia clans could guarantee efficiency for their brokerage, evoking Cosa Nostra (Lodato 2006). In other words, after the agrarian reforms mafiosi clans and their affiliates shifted from controlling people's labour to acting as middlemen between producers and the market.

Threatened by low prices and no bargaining power in the late 1950s, peasants, who themselves or through their broader families (genealogically and laterally) were aware of previous bracciante struggles, faced new forms of dependence induced by sensali control of prices and markets. This gave rise to further struggles that aimed to address market insecurity. The peasant movement recuperated, almost within a generation, the experience of braccianti mobilizations. The winery replaced land as the strategic resource around which peasants' collective claims were formulated: the peasant movement transformed itself into a massive social cooperation grounded in reaching urban markets and avoiding mafiosi brokers. 
In Alto Belice, the cooperative winery Sancipiriddu, located on the outskirts of San Giovanni and established in 1968, was the main achievement of the cooperative movement's mobilization. The offspring of a vanguard commitment of local communist peasants, with immediate experiences of mafia violence and family memories of the Fasci, Sancipiriddu began as the cooperative attempt of a few families and spread through kinship and friendship ties (Terranova 2006). It started to grow in the early 1970s, largely as a result of PCI policies. Attracting state funding, it aimed at incorporating peasants into the political system and containing the mafia's influence. This was partly due to the alliance with the village branch of the CGIL (General Chamber of Labour) union, which lobbied the PCI for support. The cooperative thus had grown out of a political movement, established itself through political institutions and played a central role in integrating people into political parties.

The actual mechanics of coop wineries were simple: each family harvests their own grapes, which are amassed to make wine on a collective vinification site. The integration of producers (circa 800 members during the 1980s and to this day) into cooperativism generated representatives within the peasant movement who translated this momentum into political power, as cooperative wineries have been led by people with explicit political commitments. Nationally, the cooperative movement developed through two opposed routes: 'red cooperatives', supported by Legacoop and the PCI; and 'white cooperatives', sustained by Unicoop and the Democrazia Cristiana (DC). What is distinctive about the Sancipiriddu cooperative is that, by pursuing links to PCI political patronage, it also sought protection against the mafia. In this way, peasants sought to de-provincialize their mafia-related concerns, making sure these were represented on the state level. Thus, with Sancipiriddu, the antimafia movement's politics signified a withdrawal from immediate post-war claims to revolutionary transformation and collective use of land.

In 1994, a local mafia clan burnt the cars and country homes of the Sancipiriddu managers. Local unionists insist this represented the mafia policy of destroying the efforts to form a cooperative winery, undertaken in order to sideline mafia brokerage (sensali), gain direct access to markets, and consolidate political alliances capable of guaranteeing long-term security against mafia. These responses affected both cooperativism and antimafia politics and constituted a backdrop against which antimafia cooperatives still operate today, and to which my informants made constant references.

\section{The contemporary context: land confiscations and antimafia cooperatives}

\section{Narrative}

After the mid-1990s, the nexus between the state and Cosa Nostra (when their relationship shifted from connivance to conflict, triggered by an escalation of violence caused by the Alto Belice mafia in the late 1970s and 1980s; Lodato 2006), most local mafiosi were arrested, some jailed for life. The 1982 Rognoni-La Torre law had already provided for the sequestering of mafia assets. Most arrests took place during the early 1990s. In 1996, Law No. 109, providing for restituting confiscated mafia properties 'back to the community', was passed (Libera 2006). Today, antimafia cooperatives cultivate land confiscated from the Alto Belice mafia between 1996 and 2009, and bestowed on the cooperatives via a state apparatus, the 'A.B. Consortium'. Following the Consortium's expansionary promotion to accommodate the land 'restituted to the community', three new coops - the Falcone, Borsellino and Liberanima - were born. The Falcone was established in 2001 and the Borsellino in 2006, after public competitions organized by the Consortium. Another coop, the Lavoroealtro, 
dated from 1998, and had been allocated land from the municipality of Corleone. The overall political situation, informed by the antimafia-sympathetic, urban civil society mobilizations of the 1990s had created an apparent antimafia consensus among some local politicians.

Parallel to claims over continuing the antimafia movement's tradition, there are other continuities with history: the work of the Consortium in distributing the confiscated land resources amounts to a small-scale legalist agrarian reform, which stands as a metaphor for revolutionary legality. The Consortium was delegated to distribute all confiscated land within the eight municipalities of Alto Belice and oversee its use. The municipalities retain ownership of the confiscated assets, the cooperatives holding only their usufruct.

Reading Consortium leaflets on 'reconstituting unlawfully usurped land back to the 'collectivity', the confiscations draw, ideologically, on the revolutionary interlude of the late 1940s, the only period in Sicilian history when land was collectively held. The identification of community and state is thus partly rooted in this reading of the historical circumstance. Moreover, judging from the Consortium's rhetoric, when the state appropriated the assets from mafia landowners, this land confiscation took place on a unique basis. In this picture the Consortium president, Matteo Marazi, argued that state intervention 'corrects' the mafioso 'usurpation' of land that was 'originally in the common domain' and available to all. Arlacchi's extensive arguments on the theme of 'mafia primitive capital accumulation' (1986) in hindsight seems relevant to the (still on-going) state confiscations project. This selective view of history omits the intricately stratified system of land tenure in Sicily, as it makes claims to a 'community' of interests across classes of landowners.

The first property to be allocated to a cooperative, in 1999, was a vineyard previously owned by mafia capo Totò ('The Beast') Riina, bestowed on the Lavoroealtro cooperative in Corleone. Confiscations hit mafiosi who had been imprisoned for life for their involvement in heroin trafficking and hundreds of assassinations between 1982 and 1996. The resulting antimafia cooperatives are interpreted as continuous with earlier peasant struggles by my research participants in a variety of ways as they negotiate their own location in antimafia history and Sicilian agrarian cooperativism. In their commemorations, activism and strategic alliances they revisit and remake the antimafia historical narrative so as to justify their contemporary activity. Two ethnographic examples are discussed, in that perspective.

Members of the antimafia cooperatives locate the 'deep historical origins of the antimafia movement' in the history of the Sicilian Fasci. I participated in one public commemoration of antimafia history held in memory of Bernardino Verro, which took place in front of his statue in Corleone's main town park. People working for the antimafia cooperatives told me that it was an 'annual event in memory of a peasant leader who paid for his antimafia commitment with his life'. Amongst the attendees were Corleone's mayor and trade unionists. They commemorated the Fasci leader Verro without mentioning his onetime mafia affiliation, indeed stressing his 'sacrifice' in the struggle against the mafia. Corleone's mayor read out a list of people who had been assassinated by local mafiosi because of their antimafia activity. In a narrative genealogy commencing with Verro, 'the antimafia forefather', the list included people as diverse as Placido Rizzotto (a communist trade unionist) and Carlo Alberto Dalla Chiesa (a military police general).

This commemorative event illustrates how the antimafia legacy is renegotiated today. Current antimafia activists separate historical actors from their time's messy contingencies, to construct a genealogy of names retrospectively cast as 'those sacrificed in the antimafia 
movement'. The contemporary antimafia cooperatives see themselves as the movement's continuation and their unique heirs, able to revisit and represent its legacy. Activists, in such commemorative narratives, evoke a 'selective tradition' comparable to the cultural expressions used by labour aristocracies, as Gavin Smith notes, to 'represent' the 'cultural survival' of working class traditions and struggles $(1999,30)$. The far-right position of the mayor of Corleone is indicative: he privately told me at the Verro event that he felt isolated, as his antimafia commitment derived from the 'fascist antimafia struggle', while contemporary antimafia cooperatives identified with the communist peasant tradition of Alto Belice.

Similar to building on the Fasci tradition, my interlocutors annually participate in the solemn commemoration of Portella della Ginestra - site of the most dearly felt May Day celebrations in Sicily, and one of the most important in Italy. Thirteen rocks lie in symbolic representation of the thirteen people shot dead in the tragic event. A sad poem in the Sicilian dialect is carved on a fourteenth rock, the 'stone of Barbato'. It is widely believed in Alto Belice that Portella was the first of many ambiguous violent eruptions that over the following decades expressed a hidden mafia-state coalition. On May Day 2009, alongside antimafia cooperative members, committed unionists marched in the morning from Piana (4 km away) to the site. They were joined there by hundreds of families coming from Palermo in a convoy of cars, parked for a couple of kilometres along the main road linking San Giovanni to Piana. A local brass band played throughout, adding a suggestive note to the day. The celebratory feel peaked when antimafia activists walked to the 'stone of Barbato' to lay their commemorative offerings. Contemporary antimafia cooperatives invest in projects of 'social tourism', which included visits to Portella. During the day, urban visitors sit next to Portella's rocks and hear a guide narrate the 1947 events. Young Palermitans seasonally employed as guides on day contracts by the cooperative Falcone, narrated the Portella events by stating that 'the peasants were communists for a piece of bread'. This is characteristic of how contemporary antimafia cooperatives downplay issues regarding the 'revolutionary legality' of Alto Belice peasants in favour of promoting (and reading historical events through) a moderate political discourse, recognizing the importance of employing legality (legalità) while de-emphasizing the politically radical context in which it developed.

Some of the activity of negotiating the movement's legacy is rooted in the management not of ideologized claims to ideas but to material possessions, including land. Today the Falcone antimafia cooperative owns the usufruct of a plot confiscated from a Corleonese mafioso in the Drago area, outlining a tangible continuity, linking contemporary antimafia cooperatives to the antimafia movement's past. Local narratives claim that this tract of land was the very place where trade unionist Placido Rizzotto made a passionate speech to the gathered braccianti before they occupied the estate, faced with the mafia's gabelloti violence. The mafia assassinated him in 1948 (Paternostro 1994).

\section{Analysis}

Anthropologists have noted how, in Italy, the Communist Party (PCI) assisted rural workingclass people to develop a sense of citizenship and be integrated into Italian politics (Shore 1990; Li Causi 1993). In Tuscany, the PCI was

the movement, which produced an historic transformation of peasants into citizens, able for the first time to claim rights and participate in a political and civic culture ... 
[and] should be assessed on the same terms as other civil rights movements. (Pratt 2003, 85)

The specificity of Sicily in this citizenship-building configuration, as regards rural communism (represented by braccianti unionists and backed by PCI politicians) is that it was co-articulated with the pursuit of 'revolutionary legality'.

The emergence of 'revolutionary legality' is critical because it marks out how Sicily is different from other cases in which land occupations are self-consciously in defiance of a legal order (see, for instance, Sitrin 2012) - but also because, although born in the rural areas, it developed with the civic engagement of the urban antimafia later. Sicily in the late 1940s became a point of compromise, where leftist politicians managed to get a legal framework friendly to occupations and cooperativization organized by landless workers, because conservative forces assumed that these would never be enforced; mafia was the on-theground force that ensured this. This signified an unusual situation in which occupations were often at least ostensibly legal. This different orientation to legality in the Sicilian Left is central to current antimafia configurations (Rakopoulos 2011, 2014, 115).

The negotiation of this legacy is tense. As Smith notes, activists 'select out from and reformulate various patterns of tradition' $(1999,188)$; this also characterizes the antimafia cooperative leaders' depiction of the area's cooperativism and antimafia history. Cooperativism in Sicily mingled saliently with the antimafia movement as cooperative models are adaptable to local contexts - and give voice to inchoate local desires. This approach shows that cooperativism has been a 'modular' notion (sensu Anderson) both in the specificities of its historical manifestations and in the ways people reproduce it and commemorate it today. Its local development embraced the antimafia movement and evolved through it.

Thus there are reasons to qualify the picture of the historical process peaking in the contemporary cooperatives. Overall, despite the claims to 'continuity' with the struggles of the antimafia peasant movement, this inspiration was ideological rather than material and direct. None of the many people who had been involved in previous social or specifically antimafia struggles was involved in the newly created cooperatives. Their inspiration from 'red' cooperativist models came from their administrators' ideological sympathy with the historical peasant movement, their present-day collaboration with 'red' consumer coops in northern Italy, and involvement in progressive Palermitan civil society. As a proportion of the local population, participation in the cooperatives was small (about 150 people's livelihoods are based on income from the cooperatives). Unlike the history they drew from and referred to, these cooperatives could not accommodate massive popular participation and were not grassroots, in that the state established them.

\section{Conclusion: modulations of antimafia and cooperatives}

The social struggles of the antimafia movement today do not confront mafia's violence, although mafia agents are still active. Rather than having to face mafia patronage or brokerage, the contemporary antimafia cooperatives are taking over the mafia's control of material resources. The struggle is now around the usufruct rights to land and the ways that is managed vis-à-vis the local social arrangements around the land. While in the past cooperatives were channels to avoid mafia influence (gabelloti patrons, sensali brokers), 
antimafia cooperativism today aims at attacking mafia: antimafia has become the end of cooperativism, not its means.

Contemporary antimafia cooperatives capitalize on both traditions described through the historical discussion above: the post-reform autonomous producers' and the pre-reform workers' cooperativism. Organizationally, they are workers' cooperatives with an explicit antimafia stance, more akin to 1940s Alto Belice cooperativism. At the same time, however, they retain elements of producers' cooperativism in that they are supported by the state (in a configuration in which politics has shifted against the mafia), hence resembling the cooperativism of the 1960s and onwards. Their commemorations and general rhetoric draw on both these traditions: their members speak of 'thin red lines', linking these experiences. The convergence between (most) peasants' positive stance towards law as a means of change and (some) politicians' support for the peasant struggles produced a form of 'revolutionary legality' that has, to a degree, been rejuvenated in today's antimafia movement. Its actors' claims to 'revolutionary legality', their rhetoric of 'reclaiming the commons', and the fact that they do not own the land they cultivate, having only usufruct rights to it, strongly echo older developments of Sicilian antimafia cooperativism. This resemblance is, importantly, used ideologically by cooperative administrators. Antimafia mobilization is based on a model of cooperativism akin to collectivism: the peasants set up worker-cooperatives, based on land owned by the state. This forms collectivist claims, which are unrealistic, as the Consortium restitutes land back to an imaginary 'collective'.

Nevertheless, this (largely imagined) legacy has to be taken into account. As discussed, the relevant literature on antimafia in Sicily has focused mainly on urban processes, and this article aims to historicize actual material processes of agrarian transformation in rural Sicily, done from an antimafia perspective. Moreover, the article has shown the particularities of an uncomfortable interrelationship in the modernization of rural Sicily. Specifically, the mafia's continuity as an organization and its strategic transformation from a pre-agrarian-reform network of violent gabelloti patrons to a post-agrarian-reform nexus of coordinated sensali brokers was crucial for the intersections of political economy and culture in Alto Belice. Mafia activity and peasant organization against it - as well as the local interpenetration of antimafia and cooperative formations - have conditioned local particularities of cooperativism and political culture. This interpenetration, despite having been developed in different forms between state, mafia and peasants, rendered the cooperative organization of production and antimafia mobilization almost inseparable. These values interacted through a range of configurations involving state and markets and were formed through peasant struggles, originally centred on accessing land before the agrarian reform and on accessing markets, after it. Contesting mafiosi shaped the peasant movement asantimafia, contributed to the establishment of local cooperative wineries and, through them, to wider political structures, such as the PCI.

The antimafia phenomenon arose amidst the tensions between social movements (focused on acquiring land or accessing markets) and the mafia has been, arguably, central to the modernization process of Sicily. While the mafia itself has been analysed as a vector of modernity, this interrelationship and conflict still needs building upon. On an island where, arguably, the mafia has been modernization's main 'protagonist' (Lupo 2011, xv), as illuminated by a continuously growing literature (Schneider 2002), it is expected that, as the analysis of mafia as 'mediating' modernity runs (Schneider and Schneider 1976), Sicily has seen 'modernization without development' (cited in Fiume 2006, 42). In this vein, historians and anthropologists have argued that the modern and flexible mafia rose through Sicily's 
dislocated route towards modernization (Blok 2000; Dickie 2004). Following this, the antimafia is similarly a modern phenomenon; studying it tackles not only how peasants make their own history in conditions they do not choose (Mcmichael 2008), and in an Italian tradition of 'resistance' (Moroni 2010), but also how this history is used in contemporary agrarian entrepreneurial contexts and current evaluating registers of 'resistance', as per the Alto Belice antimafia cooperatives. This historical and current tradition has developed alongside of (and inspired) civic engagement in Sicilian urban settings; analysing the antimafia movement's rural roots and presence can help to illuminate broader processes of change in Sicily and beyond.

\section{Notes}

${ }^{1}$ The village where my fieldwork was based is San Giovanni; research also involved participants from other Alto Belice villages, such as Corleone.

${ }^{2}$ In Sicily, a bracciante is a person who works as a field hand, making a living through daily wage labour in an agrarian context. Historically, braccianti refers to landless peasants.

${ }^{3}$ Decreti Gullo, notably Decree Number 279, 19 October 1944 ('concessions of uncultivated land to farmers').

${ }^{4}$ In the Coalition, the conservative Christian Democracy (DC) party was in the majority but the PCI also participated. The Coalition collapsed due to Cold War tensions when the Communists were thrown out of government in 'the May 1947 crisis' -partly induced by the dramatic events of Portella (Ginsborg 2003: 111-113).

5 'The cooperative is the cell of the future socialist organization', noted Gullo (in Rossi-Doria 1983, 106).

${ }^{6}$ The scheme I suggest is not all-encompassing, and allows for differentiated routes to development of collective action - as well as for its disintegration. For instance, the collapse of the regional association of Left cooperatives (USCA) was due to corrupt practices internal to USCA rather than the outcome of mafia activity (Sabetti 2002, xi).

\section{References}

Anderson, Benedict. 2006 [1983]. Imagined Communities: Reflections on the Origin and Spread of Nationalism. London: Verso.

Arlacchi, Pino. 1986. Mafia Business: The Mafia Ethic and the Spirit of Capitalism. London: Verso.

Bandiera, O.2003. "Land Reform, The Market For Protection, And The Origins Of The Sicilian Mafia: Theory And Evidence.” Journal of Law, Economics, and Organization 19 (1): 218-244.

Blim, Michael. 2006. "Defining a Field, Describing a World: Jane and Peter Schneider and the Study of Modern Italy." Journal of Modern Italian Studies 11 (1): 1-15. 
Blok, A.2000. Honour and Violence. Malden, MA: Polity Press.

Blok, A.1988 [1974]. The Mafia of a Sicilian Village, 1860-1960: A Study of Violent Peasant Entrepreneurs. Cambridge: Polity Press.

Casarrubea, G.2005. Storia Segreta Della Sicilia: Dallo Sbarco Alleato a Portella Della Ginestra. Milan: Tascabili Bompiani.

Cole, J.2007. Dirty Work: Immigrants in Domestic Service, Agriculture, and Prostitution in Sicily. Lanham, MD and Plymouth: Lexington Books.

Cole, J.1997. The New Racism in Europe: A Sicilian Ethnography. Cambridge: Cambridge University Press.

Davis, J.1996. “Changing Perspectives on Italy's 'Southern Problem'.” In Italian Regionalism: History, Identity and Politics, edited by C. L.Levy. Oxford: Berg Publishers.

Di Matteo, S.1967. Anni Roventi. La Sicilia Dal 1943 Al 1947, etc. (Cronache Di Un Quinquennio.). Palermo: G. Denaro.

Dickie, John.2004. Cosa Nostra: A History of the Sicilian Mafia. London: Hodder \& Stoughton.

Edelman, M.2005. "Bringing the Moral Economy Back in to the Study Of 21st-Century Transnational Peasant Movements.” American Anthropologist 107 (3): 331-345.

Fiume, G.2006. “A Changing Sicily: Homage to Jane and Peter Schneider.” Journal of Modern Italian Studies 11 (1): 37-60.

Follain, J.2005. Mussolini's Island: The Battle for Sicily 1943 by the People Who Were There. London: Hodder \& Stoughton.

Ganci, M. S.1977. I Fasci Dei Lavoratori: Saggi E Documenti. Roma: Salvatore Sciascia.

Girolamo, U. D.2009. Mafie, Politica, Pubblica Amministrazione: è Possibile Sradicare il Fenomeno Mafioso dall'Italia? Naples: Guida Editori.

Gambetta, D.1996. The Sicilian Mafia: The Business of Private Protection. Harvard, MA: Harvard University Press.

Ginsborg, P.2003. A History of Contemporary Italy: Society and Politics. New York: Palgrave MacMillan.

Giorgio, A., and A.Cento Bull, eds. 2005. Speaking Out and Silencing: Culture, Society and Politics in Italy in the 1970s. Oxford: Legenda.

Gramsci, A.2010. Prison Notebooks. New York: Columbia University Press.

Gramsci, A.1971. Selections from the Prison Notebooks of Antonio Gramsci. London: Lawrence and Wishart. 
Hobsbawm Eric, J.1974. "Peasant Land Occupations.” Past \& Present 62 (1): 120-152.

Gunnarson, C.2008. Cultural Warfare and Trust: Fighting the Mafia in Palermo.

Manchester: Manchester University Press.

Jamieson, Alison. 2000. The Antimafia: Italy's Fight Against Organized Crime. London: Macmillan.

Li Causi, Luciano. 1993. Il Partito a noi ci ha Dato! Antropologia Politica di una Sezione Comunista Senese nel Dopoguerra. Siena: Laboratorio Etnoantropologico.

Lodato, Saverio. 2006. Trent'anni Di Mafia. Milan: BUR saggi.

Lupo, Salvatore. 1981. Blocco Agrario e Crisi in Sicilia tra Le Due Guerre. Naples: Guida.

Lupo, Salvatore. 2011. History of the Mafia. New York: Columbia University Press.

Mcmichael, P.2008. "Peasants Make Their Own History, But Not Just as They Please...." Journal of Agrarian Change 8 (2-3): 205-228.

Moroni, F.2010. L'Italia che Resiste: Storia e Ritratti di Cittadini Controcorrente. Monte Porzio Catone: Effepi Libri.

Orlando, Leoluca. 2003. Fighting the Mafia and Renewing Sicilian Culture. New York: Encounter Books.

Paternostro, Dino. 1994. L'Antimafia Sconosciuta: Corleone 1893-1993. Palermo: La Zisa.

Pratt, J. C.2003. Class, Nation and Identity: The Anthropology of Political Movements. London: Pluto Press.

Pratt, J. C.1994. The Rationality of Rural Life: Economic and Cultural Change in Tuscany. Chur, Switzerland: Harwood Academic.

Rakopoulos, Theodoros. 2014. "Food Activism and Antimafia Cooperatives in Contemporary Sicily." In Food Activism: Agency, Democracy and Economy, edited by Carole Counihan, and Valeria Siniscalchi. New York: Berg.

Rakopoulos, Theodoros. 2011. From the 'Moral Question' of the Communists to 'Legalità' of the NGOs: Transparency and anti-mafia rhetoric in contemporary Italian activism, $R e$ Public, Contested Transparencies, special issue 11. Accessed http://www.republic.gr/en/?p $=4260$.

Renda, F. 1977. I Fasci Siciliani, 1892-94. Torino: Einaudi.

Robb, P. 2009. Midnight in Sicily: On Art, Food, History, Travel, and Cosa Nostra. London: Harvill Press.

Romano, S. F.1959. Storia dei Fasci Siciliani. Bari: Laterza. 
Rossi-Doria, A.1983. Il Ministro e i Contadini: Decreti Gullo e Lotte Nel Mezzogiorno, 1944-1949. Roma: Bulzoni.

Sabetti, F.2002. Village Politics and the Mafia in Sicily. Montreal: McGill-Queen's University Press.

Sampson, S.2005. "Integrity Warriors: Global Morality and the Anti-Corruption Movement in the Balkans." In Corruption: Anthropological Perspectives, edited by D. Haller and C. Shore. London: Pluto Press.

Santino, Umberto. 2006. Dalla Mafia alle Mafie: Scienze Sociali e Crimine Organizzato. Soveria Mannelli: Rubbettino Editore.

Santino, Umberto. 2009. Storia del Movimento Antimafia: Dalla Lotta di Classe all'Impegno Civile. Rome: Editori Riuniti.

Schneider, A. 1990. Emigration und Rückwanderung von 'Gastarbeitern' in einem Sizilianischen Dorf. Frankfurt, Bern, New York, and Paris: P. Lang.

Schneider, P.2002. “On Mafiology.” Journal of Modern Italian Studies 7 (1): 145-149.

Schneider, Jane, and PeterSchneider. 1976. Culture and Political Economy in Western Sicily. New York [etc]: Academic Press.

Schneider, Jane, and PeterSchneider. 1996. Festival of the Poor: Fertility Decline and the Ideology of Class. Tucson, AR: University of Arizona Press.

Schneider, Jane, and Peter Schneider. 1997. "From Peasant Wars to Urban Wars: The Antimafia Movement in Palermo." In Between History and Histories: Silences and Commemorations, edited by G. Sider and G. Smith. Toronto: University of Toronto Press.

Schneider, Jane, and Peter Schneider. 2005. "Mafia, Antimafia, and the Plural Cultures of Sicily." Current Anthropology 46 (4): 501-520.

Schneider, Jane, and Peter Schneider. 2003. Reversible Destiny: Mafia, Antimafia, and the Struggle for Palermo. Berkeley, CA: University of California Press.

Schneider, Jane, and Peter Schneider. 2006. "Sicily: Reflections On Forty Years Of Change 1.” Journal of Modern Italian Studies 11 (1): 61-83.

Schneider, Jane, and Peter Schneider. 2002. "Suggestions from the Antimafia Struggle in Sicily." Anthropological Quarterly 75 (1): 155-158.

Scolaro, G.2008. Il Movimento Antimafia Siciliano - Dai Fasci Dei Lavoratori All'omicidio Di Carmelo Battaglia, Lulu.com.

Shore, Chris. 1990. Italian Communism: The Escape from Leninism: An Anthropological Perspective. London: Pluto Press. 
Sitrin, Marina. 2012. Everyday Revolutions: Horizontalism \& Autonomy in Argentina. London: Zed Books.

Smith, G. A.1999. Confronting the Present: Towards a Politically Engaged Anthropology. Oxford: Berg Publishers.

Terranova, G.2006. L'Uomo Delle Vigne. Legacoop.

\section{Official Materials}

Libera. 2006. La Mafia Restituisce Il Maltolto. Mostra Sui Beni Confiscati Alle Mafie. Edizioni Libera.

Pati, D. 2010. "La Confisca dei Beni alle Mafie e il Loro Riutilizzo per Finalita`Sociali." http://www.avvisopubblico.it/categorie/pubblicazioni/allegati/relazione_pati_ beni_confiscati_campo 